\title{
Food Justice, Nervios, and the Unequal Burden of Misery
}

\author{
Michael McQuaide ${ }^{1}$
}

Global labor markets under neoliberal capitalism create all sorts of pressures for migrant laborers from the global South to migrate to the US for work. In the case of Ecuadorans, this is typically movement for labor in the food industry. This paper is a reflection on one of the primary damages to sending families of this global process-a sickness labeled as nervios. Reflecting on years of traveling to Ecuador and speaking with people there in a place-based classroom teaching about globalization processes, I outline nervios as an illness that is often brought on by the outward migration by workers reacting to the discipline of global labor markets. I argue that conceptions of food justice might serve as a way of reducing/addressing nervios and the unequal burden of misery visited upon families and communities in Ecuador under the existing organization of global capital. [Article copies available for a fee from The Transformative Studies Institute. E-mail address: journal@transformativestudies.org Website: http://www.transformativestudies.org (02014 by The Transformative Studies Institute. All rights reserved.]

KEYWORDS: Food Justice, Nervios, Undocumented Migration, Global Labor Markets, Injustice, Family Separation.

\footnotetext{
${ }^{1}$ Michael McQuaide, Ph.D., earned a B.S. degree in psychology from Florida State University in 1973. His Master's Degree (1976) and Ph.D. (1979) in sociology were earned at Penn State University. McQuaide joined the sociology faculty at Oxford College of Emory University in 1979. Tenure was granted in 1984 and promotion to Full Professor was granted in 1996. McQuaide's teaching and research interests include social gerontology, medical sociology, and globalization issues. Address correspondence to: Michael McQuaide, Professor of Sociology, Oxford College of Emory University; e-mail: MMCQUAI@emory.edu. Acknowledgments: The author offers grateful thanks to Juan Gabriel Carrasco and Sylvia Sanchez for their role in serving as trusted guides and interpreters in Ecuador. Thanks to Stacy Bell, whose careful guidance directed the conversations into deeper insights. Gratitude goes to Sarah Bankston, Teaching and Learning Librarian, for capable assistance in the literature search.
} 